Published online 2016 December 28.

Letter

\title{
Zika Virus Infection in Thailand: How Success in Control?
}

\author{
Viroj Wiwanitkit ${ }^{1, *}$ \\ ${ }^{1}$ Visiting Professor, Hainan Medical University, China \\ "Corresponding author: Viroj Wiwanitkit, Wiwanitkit House, Bangkhae, Bangkok, Thailand 10160. E-mail: wviroj@yahoo.com
}

Received 2016 November 01; Accepted 2016 December 27.

Keywords: Zika, Virus, Control

\section{Dear Editor,}

Zika virus infection is a present global problem. In the Southeast Asia, this disease has become a newly emerging problem (1). In Thailand, the disease has just been declared as a disease under control and the legal notification of the case is needed. Here, the author summarizes the current situation of the success in the attempt to control this disease in Thailand. At present (October 31, 2016), there is already an accumulation of 97 cases of Zika virus infection in 10 provinces in Thailand. According to the control process, only 2 provinces are still in the outbreak situation. This can imply a good infection control in this area. In fact, Zika virus infection is a similar infection to dengue which is a very common problem in Thailand and this might be why a fast disease control can be seen in this area. Experience in the control of vector mosquito for dengue situation could have been useful in the control of Zika virus infection.

\section{Footnote}

Conflict of interest: None declared.

\section{References}

1. Wiwanitkit V. The current status of Zika virus in Southeast Asia. Epidemiol Health. 2016;38:2016026. doi: 10.4178/epih.e2016026. [PubMed: 27336445]. 